\title{
Biomarker Approach in Marine Monitoring and Assessment: New Insights and Perspectives
}

\author{
T. Schettino, R. Caricato, A. Calisi, M.E. Giordano and M.G. Lionetto* \\ Department of Biological and Environmental Sciences and Technologies (DiSTeBA), University of Salento, Italy
}

\begin{abstract}
The measurement of cellular and sub cellular responses to chemical contaminants (referred to as biomarkers) in living organisms represents a recent tool in environmental monitoring. It answers to the need to detect exposure and to assess effects of pollutants on biota. Biomarkers have recently become an integral component of environmental monitoring programmes of marine environments in several countries as a supplement to the commonly used contaminant monitoring. The review reports and analyzes new insights and perspectives in the biomarker approach, including its recent application to the detection of the impact of biological pollution in marine environment.
\end{abstract}

Keywords: Biomarkers, biomonitoring, pollution.

\section{INTRODUCTION}

Marine chemical pollution has become of global concern in recent years. The marine environments are affected by either point or non point source pollution. Chemicals such as oil-based products, pesticides, fertilizers, heavy metals, accidental oil spills, runoff from coastal areas, antifouling compounds, plastic materials [1-5] all impact marine environments.

Quality assessment of marine water has become of relevance in recent years. In Europe, coastal waters are protected by the Water Framework Directive (WFD) and the seas are protected by the Marine Strategy Framework Directive (MSFD). Member States are required to achieve or maintain 'good environmental status' within their marine waters by 2020 under the MSFD. There is general agreement that certain goals must be reached in order to improve the chemical and ecological status of the marine environment, such as: decrease the concentrations of priority chemical compounds, do not exceed the threshold set for a chemical compound, and decrease the effects on populations and individuals [6]. To reach these goals, water quality must be assessed and monitored.

For this reason the need to develop new methodological approaches for the identification, assessment and management of the risks for biota arising from chemical pollutants discharged to marine environment has widely grown. The requirement of an integrated chemical and biological approach in marine environment monitoring has received increasing attention in the last years $[7,8]$. There is a growing awareness that focusing on chemical data alone of pollutant concentration in environmental matrices (water and sediments) is not sufficient to reliably assess the potential

*Address correspondence to this author at the Department of Biological and Environmental Sciences and Technologies (DiSTeBA), University of Salento, Via prov.le Lecce-Monteroni, 73100 Lecce, Italy; Tel: $+39-0832$ 298694; Fax: +39 0832 298626; E-mail: giulia.lionetto@unisalento.it risks of the complex mixture of contaminants that can be present in the environment. In fact, numerous environmental factors influence the bioavailability of pollutants to organisms: temperature fluctuations, rainfall, $\mathrm{pH}$, salinity, sediment type. In addition, numerous chemicals can be present simultaneously in the marine environment and chemical interactions in a mixture can cause complex and substantial changes in the chemical characteristics of pollutants, including bioavailability and toxicity. In general the adverse effects of a mixture of chemicals may not correspond to that predicted from data on pure chemical compounds. Even using biotic monitoring of chemical residue levels in the organism tissues, there are considerable difficulties in knowing the effects of this level of chemicals in the organisms. Therefore, the need to detect the biological effects of chemical contaminants also at low concentration and in complex mixture has increased the study of the relationships between exposure to chemical contaminants and alterations in several molecular and cellular processes in the organisms [9] in order to use the latter as markers (commonly referred to as biomarkers) of exposure and early response to chemical contaminants. The inclusion of the biomarker approach in field surveys of contaminated marine environments is increasingly reported in the last years. This arises from the fact that exposure and effect assessment of contaminants in marine environment is necessary for decision-making related to ecosystem's service and habitat protection, implementation of remediation procedures, or for impacted site monitoring programs.

\section{BIOMARKERS AS TOOLS FOR POLLUTANT EXPO- SURE DETECTION AND EFFECT ASSESSMENT}

A biomarker is defined as a "biochemical, cellular, physiological or behavioural variation that can be measured in tissue or body fluid samples, or at the level of whole organisms, to provide evidence of exposure and/or effects from one or more contaminants" [10]. The effects of contaminants at lower levels of biological organization (e.g. biochemical, cellular, physiological) in general occur more 
rapidly than those at higher levels (e.g., ecological effects) and therefore may provide a more sensitive early warning of toxicological effects within populations [11].

Potentially, any alteration in any of the molecular, cellular, biochemical, and physiological processes occurring within an organism following pollutant exposure may be used as biomarker.

Biomarkers, in general, may be classified into biomarkers of exposure, and biomarkers of effect [12]. They can differently contribute to environmental monitoring and assessment. Biomarkers of exposure indicate that an organism has experienced exposure to a pollutant, and offer an early signal of exposure to micropollutants (Fig. 1). They can provide qualitative and quantitative estimates of exposure to various compounds. Biomarkers of exposure may have the potential to offer an alternative to some chemical analyses or to measure effects of short-lived chemicals as well as to give a more biologically relevant indication of exposure [13]. For example the detection of PAH metabolites in fish and crustaceans using fluorimetric analysis of urine and bile has been successfully used for the rapid and easy detection of exposure to PAHs [14]. Using this approach, Watson et al. [15] detected a gradient of PAH exposure in the urine of crabs along a Norwegian coastline. The measurement of detoxifying enzymes has been widely proposed as biomarker of exposure for organic pollutants in aquatic environments. Fish cytochrome P450-dependent monooxygenases play a crucial role in the metabolism of numerous endogenous and exogenous compounds. Increased cytochrome P450-dependent monooxygenases (CYP1A) and associated 7-ethoxyresorufin $O$-deethylase (EROD) activity in fish, especially in areas polluted by petroleum hydrocarbons, paper bleaching, and other industrial and city sewerage systems, are among the biological biomarkers most commonly used to observe environmental contamination occurring in these areas [16]. It has been successively used in many field studies, involving several fish species, in USA and Europe. The detection of the estrogen-inducible protein vitellogenin, (normally synthesized by the liver of nonmammalian female vertebrates during oocyte development) in male fish has been successfully utilized for detecting exposure to xenoestrogen compounds [17]. Metallothioneins are low molecular weight (6-7000 Dalton), cysteine-rich (20$30 \%$ metal-binding proteins with a high affinity for IB and IIB metal ions. These proteins are known to be involved in heavy metal homeostasis and are over-expressed in organisms experiencing high metal concentrations in their environment [18]. A number of field studies have confirmed the measurement of metallothionein concentration in mussel digestive gland and in fish liver as useful biomarker of trace metal exposure in coastal marine environmental monitoring [19-22]. Measurement of the metallothionein level is generally able to discriminate between different levels of contamination. Thus, there is a potential use of exposure biomarkers as a cost-effective primary screening tool in order to determine if more detailed chemical analyses are necessary 13].

Biomarkers of effect allow detecting early alteration in the health status of the organisms, which if sustained, may produce pathological consequences (Fig. 1). For example imposex in gastropods has been demonstrated to be a biomarker of organothin exposure and reproductive impairment, with population-level consequences. Eggshell thinning due to carbonic anhydrase inhibition by DDT in the bird female oviduct [23] has been related to reduced avian reproduction. Moreover, considering the importance of effects associated with DNA damage, genotoxicity biomarkers are considered particularly important biomarkers of effect for identification of potential risk and adverse health effects. Lysosomal membrane stability has been widely demonstrated as a good predictive indicator for cell injury and pathology and supporting evidence indicates that lysosomal membrane destabilization represents generic response to chemical stress in the animal kingdom [24-28]. In fact, lysosomal membrane stability has been used prognostically to predict liver damage and tumour progression in the liver of various fish species [29], degeneration of hepatopancreasin molluscs (e.g., blue and green mussels, freshwater bivalves and snails, periwinkles, oysters), coelomocyte damage in earthworms, as well as enhanced protein turnover (i.e., lysosomal autophagy) as a result of protein oxidation by radical attack; and energetic status (i.e., scope for growth) as a predictive indicator of fitness of individuals within a population $[24,30]$. The specificity of biomarkers to pollutants ranges from highly specific biomarkers (i.e., the enzyme aminolaevulinic acid dehydratase is inhibited only by lead) to not specific biomarkers such as immune system impairment or DNA damage. However, in some case the increasing knowledge of the biomarker response allows to more precisely understand its specificity. The case of acetylcholinesterase is an emblematic example. The enzyme acetylcholinesterase has been considered for a long time specific biomarkers of exposure/effects for organophosphate and carbamate pesticides. However, in the last years, the inhibition of acetylcholinesterase by several chemical species other than organophosphate and carbamate pesticides including heavy metals, polycyclic aromatic hydrocarbons (PAHs), detergents and components of complex mixtures of contaminants has been increasingly reported [20, 21, 31-33]. These recent findings have questioned the use of the $\mathrm{AChE}$ inhibition as a specific biomarker for organophosphate and carbamate pesticides, especially in areas contaminated by several classes of pollutants. On the other hand the interest of the use of acetylcholinesterase inhibition as an integrative measurement of the overall neurotoxic risk posed by the whole burden of bioavailable contaminants present in the environment has been received grown attention. Recently, measurements of AChE activity inhibition in fish and aquatic invertebrates as general biomarker of neurotoxicity have been successfully used in a number of field studies [20, 3436].

Therefore, the use of a suite of biomarkers with different degrees of specificity is an important aspect of environmental monitoring based on the biomarker approach. Moreover, the selection of the most useful and relevant biomarkers to use for pollutant impact assessment in aquatic monitoring has to consider certain criteria including whether a biomarker is sensitive, whether it responds in a dose- or time dependent manner to the pollutants, including how long after exposure the response lasts, whether the natural variability (i.e., season, temperature, sex, weight, age) in the biomarker response is known [13]. 


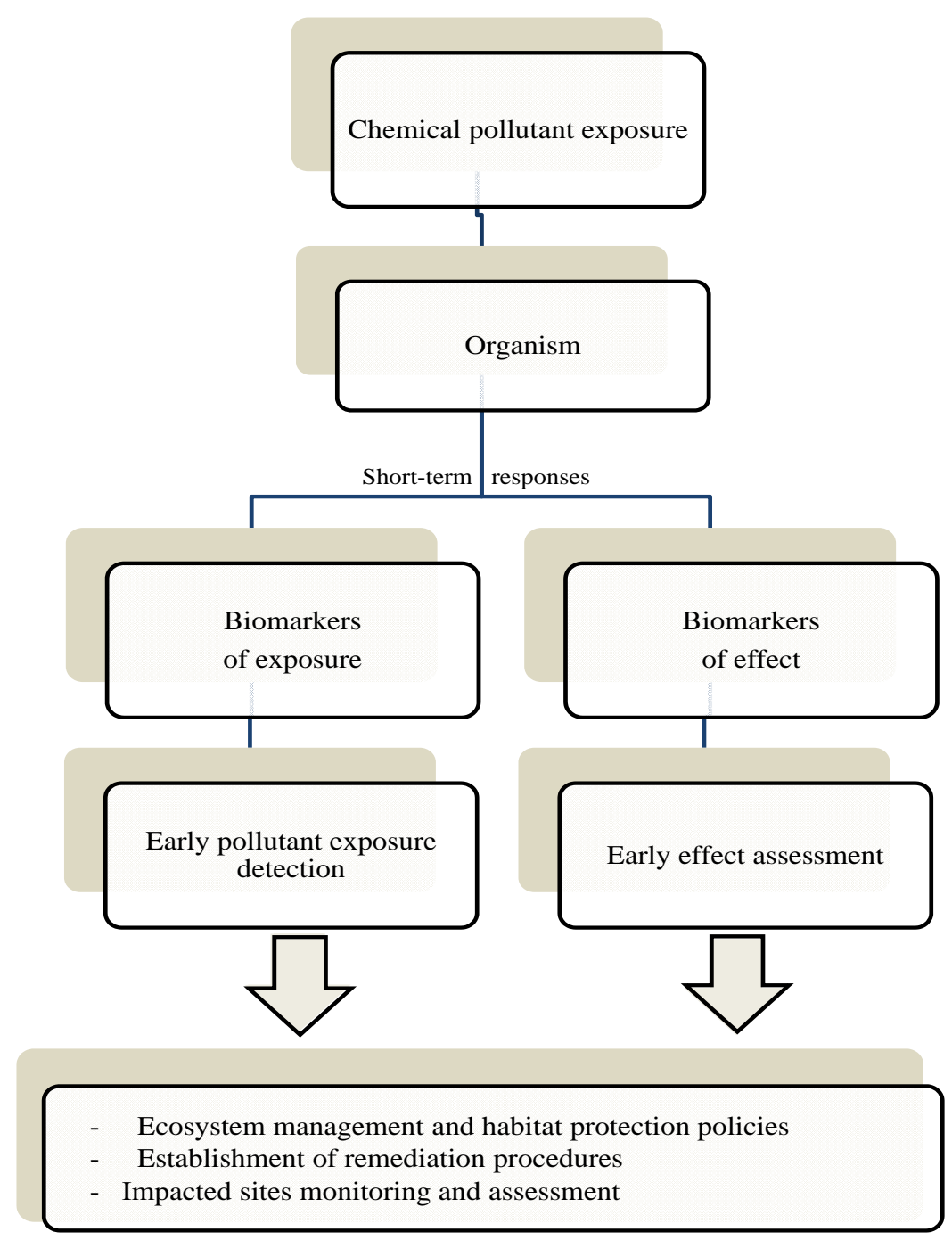

Fig. (1). Biomarkers of exposure and biomarkers of effects: their usefulness in environmental monitoring, assessment and management.

\section{A NEW GENERATION OF POLLUTION BIOMARKERS}

In the last years new diagnostic techniques, originally developed for human diseases, has been adapted and applied to environmental problems. Molecular techniques as genomics, proteomics, and metabolomics are being used to develop potential biomarkers in environmental risk assessment with extensive future perspectives.

In response to pollutants exposure, the organism reacts at multiple levels which include altering the expression of genes, protein levels, or metabolite concentrations. The particular set of genes (or proteins or metabolites) which are altered will be dependent on and specific for the pollutant's mechanism of action. The particular pattern of response therefore can represent a fingerprint for a specific pollutant exposure.

A genomic biomarker of pollution is a measurable DNA and/or RNA characteristic that is an indicator of response to pollutant exposure. It can be a measurement of the expression, function or regulation of genes. The responses of hundreds or even thousands of genes can be measured simultaneously by the DNA microarrays and accompanying statistical procedures $[37,38]$ in order to screen efficiently those genes that are responsive to pollutants. Different mechanisms of toxicity can generate specific patterns of gene expression that can potentially provide us with molecular biomarkers. The adoption of changes in gene expression in environmental toxicology has been facilitated by the availability of genome sequences for a number of key species. Several studies have been validated the use of microarrays applied to ecological relevant species, such as fish and molluscs. DNA expression array was employed to detect toxic stress response in the European flounder (Platichthysf lesus) sampled from the estuaries of the Tyne and Alde rivers in the UK [39]. A high-density cDNA microarray was applied to detect the specific responses of rainbow trout at sub lethal ranges of $\beta$-naphthoflavone, cadmium, carbon tetrachloride, and pyrene [40]. A lowdensity oligonucleotide array encompassing 24 mussel genes involved in both basal and stress response functions and a high-density microarray derived from cDNA libraries have been generated for discriminating the degree of pollution in exposed organisms in biomonitoring projects [41, 42].

Proteomics and metabolomics are now starting to be applied for studying the effects of environmental pollutants on both fish [43] and molluscs [44, 45]. Environmental 
proteomics addresses the analysis of an organism's proteome in order to detect any changes in the level of proteins/peptides in response to environmental stressors [4648]. These techniques have received an increasing attention because they offer the possibility to disclose novel mechanisms of pollutant toxic action and, therefore, show a great potential for the development of new biomarkers of exposure and effects. Metabolomics evaluate the changes in the metabolite profiles within organisms as a result of exposure to environmental stressors. Recently, H-nuclear magnetic resonance (NMR)-based chemometric analysis was applied to the marine mussel Mytilus galloprovincialis to investigate changes in the metabolic profile of digestive gland tissue as a response to exposure to chemical pollutants [49]. However further research is required for application and validation of these techniques in field monitoring in order to assess their real usefulness value in terms of costs and benefits for biomonitoring purpose.

\section{BIOMARKERS AS USEFUL TOOL FOR DETECTING SUBTLE EFFECTS OF BIOLOGICAL INVASIONS}

Besides its application in chemical pollution monitoring and assessment, recently the usefulness of the biomarker approach has been demonstrated also for the detection of the impact of alien species in marine environments [50, 51]. Alien species can cause severe changes in the ecosystem's functioning and are recently recognized as principal agents of global change [52]. About 955 alien species are reported in the Mediterranean Sea [53] and among these, the green algae Caulerparacemosa has attracted great attention. This alga, native from the south-western coast of Australia, has induced a significant seabottom landscape change in the last decades.

In two recent studies $[50,51]$ carried out along the Apulian coasts (Northern Ionian Sea, SE Italy) the authors found that $C$. racemosa changes foraging habit of the native white seabream, Diplodus sargus. In invaded areas, a high frequency of occurrence of C. racemosa in the stomach contents of this omnivorous fish was found in parallel with a significant accumulation of caulerpin, one of the main secondary metabolites of $C$. racemosa, in fish tissues. The occurrence of biochemical perturbations in fish consuming the pest alga was showed. By using biomarkers, the authors found that exposure to the alga induced stress conditions, increased metabolic activity of detoxification and, also, changes in the morphology of gross gonads (Fig. 2). Specifically, the high exposure to the alga, deduced by the high accumulation of caulerpin, seemed to trigger the activity of 7-etoxyresorufin O-deethylase (EROD), suggesting the involvement of cytochrome P450 biotransformation pathway in the metabolism of Caulerpa. Cyt P450 plays a key role in the detoxification process; however, it can increase intracellular oxyradical formation and activate certain chemicals to mutagenic metabolites, thus enhancing the likelihood of carcinogenicity. Prooxidant effects of $C$. racemosa based-diet on white sea breams were suggested by the significant modulation in the activity of catalase and glutathione peroxidases. The activation of antioxidant defences was further supported both in terms of induction of more sensitive oxidative biomarkers, i.e., glutathione S-transferases (GST) and glutathione, and as overall capability to neutralize ROS indicated by the Total
Oxyradical Scavenging Capacity. Moreover, Felline et al. [51], using micronucleus-frequencies as genotoxicity biomarker, were able to detect direct effects of algal compounds on the loss of DNA integrity, probably caused by the highly reactive intermediates produced during biotransformation and oxidative processes.

Moreover, in the same studies [50,51] the exposure to the alga was also demonstrated to induce a) alteration of the activity of the $\mathrm{Na}^{+}-\mathrm{K}^{+}$-ATPase, which is responsible for the electrochemical gradient across the plasma membrane and it is critical for the osmotic balance of the cell, the resting membrane potential, and the excitable properties of muscle and nerve cells [54-58], b) neurotoxic effects, documented by acetylcholinesterase inhibition, and c) changes in the morphology of gonads. The observed alterations may cause detrimental health status and altered behaviour in the fish, potentially preventing the reproductive success of fish population [51].

In these studies $[50,51]$ biomarkers revealed for the first time to be useful tools for the detection of the subtle effects of biological invasions in autochthonous organisms. By using biomarkers the authors evaluated early warning signals of biological responses to biological pollution that could have, in long-term perspective, great biological and ecological consequences (Fig. 2).

\section{THE DEFINITION OF A QUANTITATIVE BIOMARKER INDEX}

It is well understood that no one biomarker has been validated as unique tool of detecting specific pollutant exposure and effects. The biological responses of an organisms to pollutant exposure can be various because of the variety of pollutants that may be present in the environment. Thus, a suite of biomarkers is required to be effectively applicable in a biomonitoring programme.

By using a suite of biomarkers various attempts have been made to try and develop a quantitative biomarker index that can simplify the complex biological alterations measured by multiple biomarkers into a single, predefined quality class.

Many alternative suggestions have so far been put forward including those that use simple numerical grading indices constructed using univariate or multivariate methodologies, ranking systems and discrimination methods [7, 59-63]. Table 1 summarises the most used quantitative biomarker indexes. Adams et al. [59] described a rapid health assessment index (HAI) for fish, based on field necropsy and histological changes, in which arbitrarynumerical values were assigned to each abnormal condition based on the severity or damage incurred by each organ or tissue type, and then summed to produce an HAI value for each fish. Aarab et al. [62] described a scoring system, again for fish, in which a multi-marker pollution index was constructed by combining the discriminatory power (calculated from discriminant analysis of field survey results) and mean value of each biomarker. In this case, biomarkers were chosen to reflect the specific molecular mechanism of action of particular toxicants. In the 'bioeffect assessment index' proposed by Broeg et al. [7] only biomarkers of general toxicity were included, to screen for disturbance across different levels of biological organisation, 


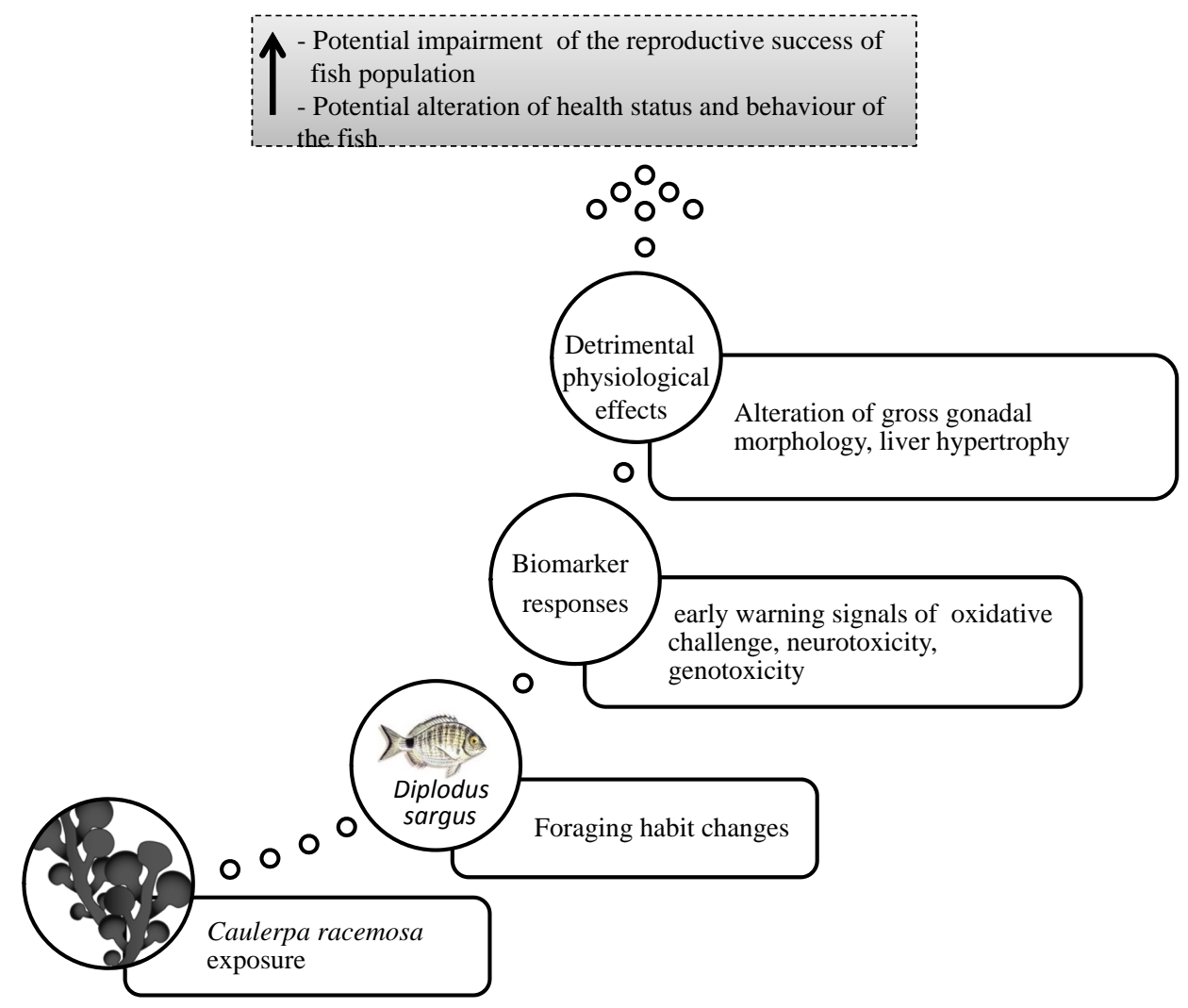

Fig. (2). Biomarker approach for the assessment of detrimental effects of the invasive alga Caulerparacemosa on the Mediterranean white seabream Diplodus sargus. Drawn on the basis of data reported by Terlizzi et al. [50] and Felline et al. [51].

with the intention of highlighting impacted areas for further study. Beliaeff and Burgeot [64] defined the Integrated Biomarker Response (IBR) index, which uses star plots to display the responses obtained from a battery of biomarkers. Star plots using IBR values instead of biomarker data make it possible to visualize between-site and/or between-survey differences for comparison with exposure conditions. Dagnino et al. [65] developed an objective decision-support or expert system capable of integrating biomarker results in mussels into a five-level health-status index. Integration of parameters includes: level of biological organization, biological significance, mutual inter-relationship, and qualitative trends in a stress gradient. The system represents a simple tool for risk assessment of the harmful impact of contaminants by providing a clear indication of the degree of stress syndrome induced by pollutants in mussels.

To answer the requirement of the European Commission's Water Framework Directive (WFD) for biological-effects endpoints to classify the ecological health of aquatic ecosystems, Hagger et al. [66] proposed the biomarker response index (BRI). The BRI, based on a suite of biomarkers at different levels of biological response at the individual level, provides an integrated relative measure of the general health status of coastal invertebrates. Using the BRI, the health of mussels (Mytilusedulis) from 10 estuaries classified by the Environment Agency of England and Wales under the WFD was compared.
Although the application and development of the more suitable quantitative biomarker index is still under debate, it is clear that the development of biomarker based indexes could minimize random errors and variability in the application of biomarkers in biomonitoring programmes.

Allen and Moore [67] pointed out the need to move the biomarker approach from descriptive to explanatory mode based on conceptual, statistical and computational modelling for the rapid assessment of the harmful impact of environmental contaminants on ecosystems. This could contribute to improve the effective interpretational capacity of the biomarker approach in the field of assessment of risk in environmental management.

\section{CONCLUSION}

Measurement of biomarker in bioindicator organisms offers great promises as a valuable tool for environmental monitoring designed for surveillance, hazard assessment, or documenting remediation in marine environments. Biomarkers have recently become an integral component of environmental monitoring programmes in several countries; however, further work is still needed to make the biomarker approach a routine, well-characterized and legally recognized tool for monitoring and assessing marine pollution.

Recently, new potentialities of this methodological approach in environmental monitoring and assessment are 
Table 1. Quantitative Biomarker Indexes

\begin{tabular}{|c|c|c|c|}
\hline $\begin{array}{l}\text { Health Assessment } \\
\text { Index (HAI) }\end{array}$ & Adams et al., 1993 [59] & $\begin{array}{l}\text { Necropsy and histological changes, hematocrit, leucocrite, } \\
\text { plasma proteins, presence of parasites }\end{array}$ & Fish \\
\hline $\begin{array}{l}\text { Integrated Biomarker } \\
\text { Response (IBR) }\end{array}$ & Beliaeff and Burgeot, 2002 [64] & $\begin{array}{l}\text { Acetylcholinesterase, metallothionein, lyosomalstability, } \\
\text { micronuclei, neutral lipida ccumulation, GST, catalase }\end{array}$ & Fish, mussel \\
\hline $\begin{array}{l}\text { Multi-marker pollution } \\
\text { index }\end{array}$ & Aarab et al., 2004 [62] & $\begin{array}{l}\text { Acetylcholinesterase, glutathione S-transferase, catalase } \\
\text { and 7-ethoxyresorufine O-deethylase }\end{array}$ & $\begin{array}{l}\text { Fish (chub, barbel and } \\
\text { trout) }\end{array}$ \\
\hline Expert System & Dagnino et al., 2007 [65] & $\begin{array}{l}\text { Lysosomal membrane stability, lipofuscin, lysosomal } \\
\text { neutral lipids and lipofuscin content, catalase, calcium- } \\
\text { ATPase, mixed function oxidases, superoxide dismutase, } \\
\text { metallothionein, micronuclei, DNA damage, } \\
\text { acetylcholinesterase, benzopyrene monooxygenase, stress } \\
\text { on stress, peroxisomal proliferation }\end{array}$ & Mussel \\
\hline
\end{tabular}

arising. As recently demonstrated [51] biomarkers can successfully be applied to the detection of the impact of other kind of environmental pollution, such as biological pollution in marine environments, contributing to understanding of how invasions can potentially affect functional properties of ecosystems.

\section{CONFLICT OF INTEREST}

The author confirms that this article content has no conflicts of interest.

\section{ACKNOWLEDGEMENTS}

The present study was carried out within the framework of projects funded by MIUR and Provincia di Brindisi.

\section{REFERENCES}

[1] Haynes D, Müller J, Carter S. Pesticide and herbicide residues in sediments and seagrasses from the Great Barrier Reef World Heritage area and Queensland Coast. Mar Pollut Bull 2000; 41: 279-87.

[2] Wiese FK, Ryan PC. The extend of chronic marine oil pollution in south eastern New found land waters assessed through beached bird surveys 1984-1999. Mar Pollut Bull 2003; 46: 1090-101.

[3] Rios LM, Moore C, Jones PR. Persistent organic pollutants carried by synthetic polymers in the ocean environment. Mar Pollut Bull 2007; 54: 1230-7.

[4] Lionetto F, Maffezzoli A. Polymer characterization by ultrasonic wave propagation. Adv Polym Tech 2008; 27: 63-73.

[5] Lionetto F, Frigione M. Mechanical and natural durability properties of wood treated with a novel organic preservative/consolidant product". Mater Design 2009; 30: 3303-7.

[6] Laane RWPM, Slijkerman D, Vethaak AD, Schobben JHM. Assessment of the environmental status of the coastal and marine aquatic environment in Europe: A plea for adaptive management. Est Coast Shelf Sci 2012; 96: 31-8.

[7] Broeg K, Westernhagen HV, Zander S, Körting W, Koehler A. The "bioeffect assessment index" (BAI): A concept for the quantification of effects of marine pollution by an integrated biomarker approach. Mar Poll Bull 2005; 50: 495-03.

[8] Damiens G, Gnassia-Barelli M, Loquès F, Roméo M, Salbert V. Integrated biomarker response index as a useful tool for environmental assessment evaluated using transplanted mussels. Chemosphere 2007; 66: 574-83.
[9] Lionetto MG, Caricato R, Erroi E, Giordano ME, Schettino T. Potential application of carbonic anhydrase activity in bioassay and biomarker studies. Chem Ecol 2006; 22: S119 -5.

[10] Depledge MH. The rational basis for the use of biomarkers as ecotoxicological tools. In: Fossi MC, Leonzio C, Eds. Nondestructive Biomarkers in Vertebrates. Boca: FL Lewis 1994; pp. 271-95.

[11] Clements WH. Integrating effects of contaminants across levels of biological organization: an overview. J Aquat Ecosyst Stress Rec 2000; 7: 113-6.

[12] Chambers JE, Boone JS, Carr RL, Chambers HW, Straus DL. Biomarkers as predictors in health and ecological risk assessment. Hum Ecol Risk Assess Manag 2002; 8:165-76.

[13] Hagger JA, Jones MB, Leonard DLP, Owen R, Gallowy TS Biomarkers and integrated environmental risk assessment: are there more questions than answers? Integr Environ Assess Manag 2006; 2: 312-29.

[14] Beyer J, Jonsson G, Porte C, Krahn MM, Ariese F.. Analytical methods for determining metabolites of polycyclic aromatic hydrocarbon (PAH) pollutants in fish bile: a review. Environ Toxicol Pharmacol 2010; 30: 224-44.

[15] Watson GM, Andersen OK, Depledge MH, Galloway TS. Detecting a field gradient of PAH exposure in decapod crustacea using a novel urinary biomarker. Mar Environ Res 2004; 58: 25761.

[16] Sen A, Ulutas OK, Tutuncu B, Ertas N, Cok I. Determination of 7ethoxyresorufin-o-deethylase (EROD) induction in leaping mullet (Liza saliens) from the highly contaminated Aliaga Bay, Turkey. Environ Monit Assess 2010; 165: 87-96.

[17] Houtman CJ, Booij P, van der Valk KM, et al. Biomonitoring of estrogenic exposure and identification of responsible compounds in bream from Dutch surface waters. Environ Toxicol Chem 2007; 26: 898-07.

[18] Viarengo A, Burlando B, Dondero F, Marrò A, Fabbri R. Metallothioneinas a tool in biomonitoring programmes. Biomarkers 1999; 4: 455-66.

[19] Lionetto MG, Giordano ME, Caricato R, Pascariello MF, Marinosci L, Schettino T. Biomonitoring of heavy metal contamination along Salento coast (Italy) by metallothionein evaluation in Mytilus galloprovincialis and Mullusbarbatus. Aquatic Conserv 2001; 11: 305-10.

[20] Lionetto MG, Caricato R, Giordano ME, Schettino T. Biomarker application for the study of chemical contamination risk on marine organisms in the Taranto marine coastal area. Chem Ecol 2004; 20: S333-43.

[21] Caricato R, Lionetto MG, Schettino T. Seasonal variation of biomarkers in Mytilus galloprovincialis sampled inside and outside Mar Piccolo of Taranto (Italy). Chem Ecol 2010; 26: 143-53. 
[22] Caricato R, Lionetto MG, Dondero F, Viarengo A, Schettino T. Carbonic anhydrase activity in Mytilus galloprovincialis digestive gland: sensitivity to heavy metal exposure. Comp Biochem Phyiol 2010; 152 C: 241-7.

[23] Bitman J, Cecil HC, Fries GF. DDT-Induced inhibition of avian shell gland carbonic anhydrase: a mechanism for thin eggshells. Science 1970; 168: 594-6.

[24] Moore MN, Allen JI, McVeigh A. Environmental prognostics: an integrated model supporting lysosomal stress responses as predictive biomarkers of animal health status. Mar Environ Res 2006; 61: 278-304.

[25] Moore MN, Allen JI, McVeigh A, Shaw J. Lysosomal and autophagic reactions aspredictive indicators of environmental impact in aquatic animals. Autophagy 2006; 2: 217-20.

[26] Calisi A, Lionetto MG, Caricato R, Giordano ME, Schettino T. Morphometrical alterations in Mytilus galloprovincialis granulocytes: a new potential biomarker. Environ Toxicol Chem 2008; 27: 1435-41.

[27] Calisi A, Lionetto MG, Schettino T. Pollutant-induced alterations of granulocyte morphology in the earthworm Eisenia foetida. Ecotoxicol Environ Saf 2009; 72: 1369-77.

[28] Calisi A, Lionetto MG, Schettino T. Biomarker response in the earthworm Lumbricusterrestris exposed to chemical pollutants. Sci Total Environ 2011; 409: 4456-64.

[29] Köhler A, Wahl E, Söffker K. Functional and morphological changes of lysosomes as prognostic biomarkers of toxic liver injury in a marine flatfish (Platichthysf lesus(L)). Environ Toxicol Chem 2002; 21: 2434-44.

[30] Nicholson S, Lam PKS. Pollution monitoring in Southeast Asia using biomarkers in the mytilid mussel Pernaviridis(Mytilidae: Bivalvia). Environ Int 2005; 31: 121- 32.

[31] Vioque-Fernández A, Alves de Almeida E, Ballesteros J, GarcíaBarrera T, Gómez-Ariza JL, López-Barea J. Dõnana National Park survey using crayfish (Procambarusclarkii) as bioindicator: esterase inhibition and pollutant levels. Toxicol Lett 2007; 168: 260-8.

[32] Bonacci S, Corsi I, Focardi S. Cholinesterase activities in the scallop Pectenjacobaeus: Characterization and effects of exposure to aquatic contaminants. Sci Total Environ 2008; 392: 99-109.

[33] Lionetto MG, Caricato R, Giordano ME, Pascariello MF, Marinosci L, Schettino T. Integrated use of biomarkers (acetylcholinesterase and antioxidant enzyme activities) in Mytilus galloprovincialis and Mullusbarbatus in an Italian coastal marine area. Mar Pollut Bull 2003; 46: 324-30.

[34] Matozzo V, Tomei A, Marin MG. Acetylcholinesterase as a biomarker of exposure to neurotoxiccompounds in the clam Tapes philippinarum from the Lagoon of Venice. Mar Pollut Bull 2005; 50: $1686-93$

[35] Gaitonde D, Sarkar A, Kaisary S, et al. Acetylcholinesterase activities in marine snail (Croniacontracta) as a biomarker of neurotoxic contaminants along the Goa coast, West coast of India. Ecotoxicology 2006; 15: 353-8.

[36] De la Torre FR, Ferrari L, Salibián A. Biomarkers of a native fish species (Cnesterodondecemmaculatus) application to the water toxicity assessment of a peri-urban polluted river of Argentina. Chemosphere 2005; 59: 577-83.

[37] Lettieri T. Recent applications of DNA microarray technology to toxicology and ecotoxicology. Environ Health Perspect 2006; 114 : 4-9.

[38] Van Stralen NM, Roelofs D. An introduction to ecological genomics. Oxford: Oxford University Press 2006.

[39] Williams TD, Gensberg K, Minchin SD, Chipman JK. A DNA expression array to detect toxic stress response in European flounder (Platichthysf lesus). Aquat Toxicol 2003; 65: 141-57.

[40] Koskinen H, Pehkonen P, Vehniainen E, et al. Response of rainbow trout transcriptome to model chemical contaminants. Biochem Biophys Res Commun 2004; 320: 745-53.

[41] Dondero F, Dagnino A, Jonsson H, Caprì F, Gastaldi L, Viarengo A. Assessing the occurrence of a stress syndrome in mussels (Mytilusedulis) using a combined biomarker / gene expression approach. Aquat Toxicol 2006; 78S: S13-24.

[42] Venier P, De Pittà C, Pallavicini A, et al. Development of mussel mRNA profiling: can gene expression trends reveal coastal water pollution? Mutation Res 2006; 602: 121-13.
[43] Samuelsson LM, Forlin L, Karlsson G, Adolfsson-Erici M, Larsson DG. Using NMR metabolomics to identify responses of an environmental estrogen in blood plasma of fish. Aquat Toxicol 2006; 78: 341-9.

[44] Rodriguez-Ortega MJ, Grosvik BE, Rodriguez-Ariza A, Goksøyr A, Lopez-Barea J. Changes in protein expression profiles in bivalve molluscs (Chamaeleagallina) exposed to four model environmental pollutants. Proteomics 2003; 3: 1535-43.

[45] Manduzio H, Cosette P, Gricourt L, et al. Protome modifications of blue mussel (MytilusedulisL.) gills as an effect of water pollution. Proteomics $2005 ;$ : 4958-63.

[46] Cristobal S. Proteomics-based method for risk assessment of peroxisome proliferating pollutants in the marine environment. Methods Mol Biol 2008; 410: 123-35.

[47] Sanchez BC, Ralston-Hooper K, Sepúlveda MS. Review of recent proteomic applications in aquatic toxicology. Environ Toxicol Chem 2011; 30: 274-82.

[48] Campos A, Tedesco S, Vasconcelos V, Cristobal S. Proteomic research in bivalves Towards the identification of molecular markers of aquatic pollution. J Proteomics 2012; 75: 4346-59.

[49] Jones OAH, Dondero F, Viarengo A, Griffin JL. Metabolic profiling of Mytilus galloprovincialis and its potential applications for pollution assessment. Mar Ecol Prog Ser 2008; 369: 169-79.

[50] Terlizzi A, Felline S, Lionetto MG, et al. Detrimental physiological effects of the invasive alga Caulerparacemosaon the Mediterranean white seabream Diplodus sargus. Aquat Biol 2011; 12: 109-17.

[51] Felline S, Caricato R, Cutignano A, et al. Subtle effects of biological invasions: cellular and physiological responses of fish eating the exotic pest Caulerparacemosa. PLoS One 2012; 7: e38763.

[52] Byrnes JE, Reynolds PL, Stachowicz JJ. Invasions and extinctions reshape coastal marine food webs. PLoS One 2007; 2: e295.

[53] Zenetos A, Gofas S, Verlaque M, et al. Alien species in the Mediterranean Sea by 2010: a contribution to the application of European Union's Marine Strategy Framework Directive (MSFD). Part I. Spatial distribution. Medit Mar Sci 2010; 11: 381-93.

[54] Lionetto MG, Maffia M, Vignes F, Schettino T. Differences in intestinal electrophysiological parameters and nutrient transport rates between eels (Anguilla anguilla) at yellow and silver stages. J Exp Zool 1996; 275: 399-405.

[55] Lionetto MG, Vilella S, Trischitta F, Cappello MS, Giordano ME, Schettino T. Effects of $\mathrm{CdCl}_{2}$ on electrophysiological parameters in the intestine of the teleost fish, Anguilla anguilla. Aquat Toxicol 1998; 41: 251-64.

[56] Lionetto MG, Maffia M, Cappello MS, Giordano ME, Storelli C, Schettino T. Effect of cadmium on carbonic anhydrase and $\mathrm{Na}^{+}-\mathrm{K}^{+}$ATPase in eel, Anguilla anguilla, intestine and gills. Comp Biochem Physiol A 1998; 120: 89-91.

[57] Lionetto MG, Giordano ME, Vilella S, Schettino T. Inhibition of eel enzymatic activities by cadmium. Aquat Toxicol 2000; 48: 56171.

[58] Schettino T, Lionetto $\mathrm{MG}$. $\mathrm{Cl}^{-}$absorption in European eel intestine and its regulation. J Exp Zool 2003; 300A: 63-8.

[59] Adams SM, Brown AM, Goede RW. A quantitative Health Assessment Index for rapid evaluation of fish condition in the field. Trans Am Fish Soc 1993; 122: 63-73.

[60] Narbonne JF, Daubeze M, Clerandeau C, Garrigues P. Scale of classification based on biochemical markers in mussels: Application to pollution monitoring in European coasts. Biomarkers 1999; 4: 415-24.

[61] Blaise C, Gagne F, Pellerin J, Hansen PD, Trottier S. Molluscan shellfish biomarker study of the Quebec Canada Saguenay Fjord with the soft shell clam, Myaarenaria. Environ Toxicol 2002; 17: $170-86$.

[62] Aarab N, Champeau O, Mora P, Daubeze M, Garrigues P, Narbonne JF. Scoring approach based on fish biomarkers applied to French river monitoring. Biomarkers 2004; 9: 258-70.

[63] Bodin N, Burgeot T, Stanisiere JY, et al. Seasonal variations of a battery of biomarkers and physiological indices for the mussel Mytilusgalloprovincialis transplanted into the northwest Mediterranean Sea. Comp Biochem Physiol 2004; 138 C: 411-27.

[64] Beliaeff B, Burgeot T. Integrated biomarker response: A useful tool for ecological risk assessment. Environ Toxicol Chem 2002; 21:1316-22. 
[65] Dagnino A, Allen JI, Moore MN, Broeg K, Canesi L, Viarengo A. Development of an Bexpert system for the integration of biomarker responses in mussels into an animal health index. Biomarkers 2007; 12: $155-72$.

[66] Hagger JA, Jones MB, Lowe B, Leonard DRP, Owen R, Galloway TS. Application of biomarkers for improving risk assessments of chemicals under the Water Framework Directive: a case study. Mar Pollut Bull 2008; 56(6): 1111-8.

[67] Allen JI, Moore MN. Environmental prognostics: Is the current use of biomarkers appropriate for environmental risk evaluation? Mar Environ Res 2004; 58: 227-32.

(C) Schettino et al.; Licensee Bentham Open.

This is an open access article licensed under the terms of the Creative Commons Attribution Non-Commercial License (http://creativecommons.org/licenses/by-nc/3.0/) which permits unrestricted, non-commercial use, distribution and reproduction in any medium, provided the work is properly cited. 